\title{
MAJESTY
}

MASPUL JOURNAL OF ENGLISH STUDIES

| ISSN 2567-0157)(Online) |

\section{Improving Students' Writing Skill through Outdoor Learning at SMA Negeri 1 Maiwa Kabupaten Enrekang}

\author{
HASAN HASAN \\ STKIP Muhammadiyah Enrekang, Indonesia
}

\section{ARTICLE INFO}

Article History:

Received 11 December 2018

Accepted 15 January 2019

\section{Keywords:}

Writing skill,

Outdoor learning

Learning Strategies

\begin{abstract}
The objective of this research was intended to know whether or not using outdoor learning strategy can improve the students' writing skill at SMA Negeri 1 Maiwa Kabupaten Enrekang. This research applied quasi experimental method with one class of experimental group and one class of control group. The researcher used pre-test and post-test in collecting data. The research population was the students of tenth grade they were X.1 class and X.2 class consist of 46 students, so the researcher took random sampling technique. The data were analyzed by finding the mean score. For collecting the data, the researcher used one instrument namely descriptive writing test to measure the students' writing ability. The result of this research showed that the student' writing description was low classification in pretest with the mean score 64.6 for experimental class and the mean score of control class was 60.8 , and it was average categorized. However, after doing the treatment through outdoor learning strategy they got good classification for Experimental group and still average classification for control group in posttest; their mean score had increased up to 78.4, for Experimental and 69.9 for control group. The data was analyzed by using t-test and the result showed that the t-test value 4.037 was higher than t-table value 2.021. It meant that there was a significance difference of students' writing ability before and after the treatment through the application of outdoor learning. It concluded that outdoor learning strategy can be used in improving writing description of the students.
\end{abstract}

@Majesty Journal 2019

$\triangle$ Corresponding author: Address : STKIP Muhammadiyah Enrekang Email : achank.hasan@gmail.com
Published by STKIP Muhammadiyah Enrekang ISSN 2567-0157 (Online) 


\section{INTRODUCTION}

Writing is an English skill defined as how to express ideas on a paper to form words, words to sentences', sentences to paragraph. The ideas of writing may be from the writer's feeling, opinion, or may come from prior knowledge such as: result of reading book, discussion or hear and watching TV. According to Wright (1989), we predict, deduce, and infer, not only from what we hear and read but from what we see around us and from what we remembering. Things that we see can affect our thinking and view especially in writing because everything what we want to write depends on our thought. So, before we write, we need to determine what we write and also the writer should have something meaningful to convey.

Mostly people have difficulties when they want to write something, may be lack of ideas, feeling bad, or may lack of vocabulary. Sometimes they lose of opinion and they can write a little only. It seems that ideas as important part in construct writing. Beside it, in speaking they can use many ways of communicate such as facial expression or body language but differently in writing we just use words to convey information. Oshima (1999) explained that keep in your mind about choice of words, grammatical structure, length of sentences, and organizing way so that the reader will receive the messages you intend to convey. We have to arrange the words based on topic clearly in order to make its meaning readable, understandable in order the readers can get the meaning easily.

Richard and Rogers (1986) stated that the most difficult part of writing is getting started; the learners do not usually have a clear idea and do not know what to write about. It is scary that they have to sit down facing a sheet of white paper with no idea, and do not know how to start and how to gather and develop ideas. To solve this problem the writer will try to combine outdoor media to find new idea in their surroundings in writing.

In this case, the researcher would try to use outdoor learning as a strategy in learning because it has enormous potential as learning medium. Outdoor learning experiences are often remembered for a lifetime. Integrating learning and outdoor experiences, whether through play in the immediate grounds or adventures further afield, provides relevance and depth to the curriculum in ways that are difficult to achieve indoors.

Outdoor learning experience provides a support and ideas which the students can build on more easily than inventing their own story all together. The Old saying that learning outdoor is a worth of thousands of words, means that it can raise the production of words and a multitude of creative and analytical thoughts. As Barnette (2006) said that visual representation invite multiple perspective, encourage exploration and engagement and increasing students investment.

\section{METHODOLOGY}

In this research, the researcher would apply quasi experimental design. Students would be divided into two classes namely experimental and control group. Both groups would be given pretest and post-test to measure students' writing skill (L. R. Gay: 2006). Experimental group would be given treatment through outdoor learning strategy whether control group only used the conventional method 
as the comparing with the experimenting. By this consideration, the researcher would see the difference of achievement between experimental group and control group. The design is presented as follows:

\begin{tabular}{cccc}
\hline Group & Pre-test & Treatment & Post-test \\
\hline $\mathrm{E}$ & $\mathrm{O}_{1}$ & $\mathrm{X}_{1}$ & $\mathrm{O}_{2}$ \\
\hline $\mathrm{C}$ & $\mathrm{O}_{1}$ & $\mathrm{X}_{2}$ & $\mathrm{O}_{2}$ \\
\hline
\end{tabular}

Figure 2 Research design (L. R. Gay: 2006)

Notation:
E : Experimental Group
C : Control Group
$\mathrm{O}_{1}$ : Pre-test
$\mathrm{O}_{2}$ : Post-test
$X_{1}$ : The treatment for experimental group

$\mathrm{X} 2$ : The treatment for control group
This section deals with the presentation of students' achievement in writing scoring classification of the students' pre-test and post-test consisted in five components of writing namely content, organization, vocabulary, language use, and mechanic (Heaton: 1991).

\section{The Students' Writing Ability}
a. Scoring classification of students' pre- test

After giving a test, the researcher analyzed the students' score of X.1 as experimental group and X.2 as control group. The scoring classification of the students score is presented in table 4.1.

\section{FINDING AND DISCUSSION}

Table 3.1. The Classification of Students' Score for Experimental Group and Control Group on Pre-test

\begin{tabular}{|lccccc|}
\hline \multicolumn{1}{c}{ Classification } & Score & \multicolumn{2}{c}{ Experimental Group } & \multicolumn{2}{c|}{ Control Group } \\
& & F & \% & F & $\%$ \\
\hline Very Good & $86-100$ & 0 & 0 & 0 & 0 \\
Good & $71-85$ & 4 & 17.4 & 1 & 4.3 \\
Average & $56-70$ & 16 & 69.6 & 18 & 78.3 \\
Poor & $41-55$ & 3 & 13.0 & 4 & 17.4 \\
Very Poor & $0-40$ & 0 & 0 & 0 & 0 \\
\hline & & 23 & 100 & 23 & 100 \\
\hline
\end{tabular}

Based on table 3.1 it is known that the students' score in pre-test result of experimental group, most of them were in average category, 4 (17.4\%) students were classified into good, $16(69.6 \%)$ students were classified into average, 3 (13\%) students were classified into poor, and there was no students' score was classified into very good and very poor.
On the other side, most of students' pre-test score of control group were categorized in average classification too, 1 (4.3\%) student was classified into good, 18 $(78.3 \%)$ students were classified into average, 4 (17.4\%) were students classified into poor, and there was no students' score was classified into very good and very poor classification. 
b. The mean score and standard deviation of student pre-test

To find out whether experimental group and control group were at the same level or not before were performed, the mean score and standard deviation of students' writing ability are presented in the following table.

Table 3.2 The Mean Score and Standard Deviation of Students' Pre-test for Experimental Group and Control Group

\begin{tabular}{|lcc|}
\hline \multicolumn{1}{|c}{ Class } & $\begin{array}{c}\text { Mean } \\
\text { Score }\end{array}$ & $\begin{array}{c}\text { Standard } \\
\text { Deviation }\end{array}$ \\
\hline Experimental Group & 64.6 & 7.9 \\
Control Group & 60.8 & 6.7 \\
\hline
\end{tabular}

Table 3.2 shows that the mean score of pre-test of experimental group and control group were categorized in average level. Therefore, the researcher concluded that the students' mean score of experimental group was relatively similar with the control group. It means that there was no significant difference between the students' writing ability between experimental and control group before treatment.

c. Scoring classification of students' post test

At the last meeting after the treatments were performed, the researcher gave the students post-test to know whether or not there would be the students' score improvement. The classification of students' score in posttest is shown in the following table.

Table 3.3 The Classification of Students' Score for Experimental Group and Control Group on Post-test

\begin{tabular}{|c|c|c|c|c|c|}
\hline \multirow[b]{2}{*}{ Classification } & \multirow[b]{2}{*}{ Score } & \multicolumn{2}{|c|}{ Experimental Group } & \multicolumn{2}{|c|}{ Control Group } \\
\hline & & $\mathbf{F}$ & $\%$ & $\mathbf{F}$ & $\%$ \\
\hline Very Good & $86-100$ & 7 & 30.4 & 0 & 0 \\
\hline Good & $71-85$ & 12 & 52.2 & 8 & 34.7 \\
\hline Average & $56-70$ & 4 & 17.4 & 14 & 61.0 \\
\hline Poor & $41-55$ & 0 & 0 & 1 & 4.3 \\
\hline Very Poor & $0-40$ & 0 & 0 & 0 & 0 \\
\hline \multicolumn{2}{|c|}{ Total } & 23 & 100 & 23 & 100 \\
\hline
\end{tabular}

From the table above it can be seen that the most of the students in experimental group were classified into good category, 7 (30.4\%) students were in very good classification, 12 (52.2\%) students were in good classification, and 4 (17.4) students were in average classification. There were not any students in poor and very poor classification. It means that the students' score range increased two levels up, from average to very good level. It shows that the students writing skill had been improved after they were taught outdoor learning strategy.

Meanwhile, in the control group, 8 (34.7\%) students were in good classification, 14 (61\%) students were in average classification, 1 (4.3\%) student was in poor classification, and none of 
students were in very good and very poor classification.

\section{d. The mean score and standard deviation of students' post-test}

The mean score and standard deviation are presented in table 4.4 to find out the difference between the posttest score of experimental and control group.

Table 3.4 The Mean Score and Standard Deviation of Students' Post-test for Experimental Group and Control Group.

\begin{tabular}{|lcc|}
\multicolumn{1}{|c}{ Class } & Mean Score & $\begin{array}{c}\text { Standard } \\
\text { Deviation }\end{array}$ \\
\hline Experimental Group & 78.7 & 9.2 \\
Control Group & 69.9 & 4.9 \\
\hline
\end{tabular}

The table above shows that the mean score of both groups are different after being given treatment. The mean score of experimental group in posttest was increased from 65.7 to 78.7 . It means that the mean score was increased from average level to good level.

On the other hand, in control group the mean score of posttest was increased from 60.9 to 69.9. Both of the mean scores were classified into average level. Even though it was increased, but the score was not significantly different. It proved that writing ability of the students who use outdoor learning strategy is better than did not use outdoor learning.

e. Test of significance (t-test)
The hypothesis stated earlier was tested by using inferential analysis. In this case, the researcher applied independent t-test analysis using SPSS 21.0 program for Windows Evaluation Version. The purpose is $t$ know whether or not the difference between the result of students' mean score on experimental group and control group is statically significant at the level of significant $\alpha=0.05$ or non-independent sample, degree of freedom $(\mathrm{N} 1+\mathrm{N} 2-2)=$ 44. The result of calculation is shown as follow:

Table 3.5 The T-test Value of the Students' Writing Ability on Experimental Group and Control Group

\begin{tabular}{|lr|c|}
\hline \multicolumn{1}{|c|}{ Variables } & T-test Value & T-test Table \\
\hline Pre-test & 1.741 & 2.021 \\
Post-test & 4.037 & 2.021 \\
\hline
\end{tabular}

Based on the student's result obtained and stated in finding above, the researcher used t-test in inferential statistic through SPSS 21.0 program for Windows evaluation version to test the hypothesis. In pre-test, the researcher found that the T-test value was lower than the T-table $(1.741<2.021)$. It means that $\mathrm{H}_{0}$ is accepted and $\mathrm{H}_{1}$ is rejected. While in relation to the finding of post-test, the $\mathrm{t}$ test value was higher than the t- table (4.037>2.021). This means that $H_{0}$ is rejected $H_{1}$ is accepted, on significant level of $\alpha=0.05$. It means that the use of outdoor learning strategy improves student's writing skill in the tenth grade at Pondok Pesantren Al-Urwatul Wutsqa Benteng Sidrap.

2. The Students' Difference Score of Pre-test and Post-test in Five Components of Writing Scoring both Experimental Group and Control Group. 


\section{a. Content}

Table 3.6 The Pre-test and Post-test Score of Content in Writing for both Groups

\begin{tabular}{|lcccc|}
\hline \multicolumn{1}{|c}{} & \multicolumn{2}{c}{ Content } & \multicolumn{2}{c|}{ Mean Score } \\
Class & Pre-test & Post-test & Pre-test & Post-test \\
\hline Experimental Group & 445 & 548 & 19.3 & 23.8 \\
Control Group & 431 & 495 & 18.7 & 21.5 \\
\hline
\end{tabular}

In the table above, in assessing content of writing shows that there was improvement after giving treatment. The score of experimental group was improved from 445 to 548 . The mean score was also improved from 19.3 to 23.8. It means that the score was improved from fair level to good level. While in control group, the score was improved, from 431 to 495 , and the mean score from 18.7 to 21.5 . The result was classified from fair level to average level, but the pre-test and post-test score were not significantly different.

We can also see that the post-test score of experimental group was higher that the control group. The mean score of post-test in experimental group was 23.8 while in control group was 21.5. it proved that the use of outdoor learning strategy has good effect to improve content of writing.

\section{b. Organization}

Table 3.7 The Pre-test and Post-test Score of Organization in Writing for both Groups

\begin{tabular}{|lcccc|}
\hline \multicolumn{1}{c}{ Class } & \multicolumn{2}{c}{ Organization } & \multicolumn{2}{c|}{ Mean Score } \\
& Pre-test & Post-test & Pre-test & Post-test \\
\hline Experimental Group & 308 & 367 & 13.3 & 15.9 \\
Control Group & 285 & 325 & 12.3 & 14.1 \\
\hline
\end{tabular}

Based the table 3.7, there was improvement in organization of writing after giving treatment. The score of experimental group had improved from 308 to 367 . The mean score was also improved from 13.3 to 15.9 . It means that the score was improved from fair level to good level. While in control group, the score was improved too, from 285 to 325 , and the mean score from 12.3 to 14.1 . There was no significant difference between the pre-test and post-test score. The result was classified from fair level to average level.

It also can be seen that the post test score of experimental group was higher than the control group. The mean score of post-test in experimental group was 15.9, while in control group was 14.1. It is a proof that the use of outdoor learning strategy has good effect to improve organization of writing. 
c. Vocabulary

Table 3.8 The Pre-test and Post-test Score of Vocabulary in Writing for both Groups

\begin{tabular}{|lcccc|}
\multicolumn{1}{c}{} & \multicolumn{2}{c}{ Vocabulary } & \multicolumn{2}{c}{ Mean Score } \\
Class & Pre-test & Post-test & Pre-test & Post-test \\
\hline Experimental Group & 306 & 370 & 13.3 & 16.0 \\
Control Group & 284 & 319 & 12.3 & 13.8 \\
\hline
\end{tabular}

Table 3.8 shows that after the treatments were given, there was improvement in vocabulary of writing. The score of experimental group was improved from 306 to 370 . The mean score was also improved from 13.3 to 16.0. It means that the score was improved from fair level to good level. While in control group, the score was improved too, from 284 to 319, and the mean score from 12.3 to 13.8 , but there was no significant difference between the pre-test and post-test score. It was classified into fair level.

The table also shows that the posttest score of experimental group still dominated the post-test score of control group. The mean score of post-test in experimental group was 16.0 while in control group was 13.8 It means that the use of outdoor learning strategy is effective to improve vocabulary of writing.

\section{d. Language Use}

Table 3.9 The Pre-test and Post-test Score of Language Use in Writing for both Groups

\begin{tabular}{|lcccc|}
\hline \multicolumn{1}{c}{} & \multicolumn{2}{c}{ Language Use } & \multicolumn{2}{c}{ Mean Score } \\
Class & Pre-test & Post-test & Pre-test & Post-test \\
\hline Experimental Group & 358 & 437 & 15.5 & 19.0 \\
Control Group & 331 & 376 & 14.3 & 16.3 \\
\hline
\end{tabular}

In the table 3.9, the score of experimental group was significantly improved from 358 to 437 . The mean score was also improved from 15.5 to 19.0, and it means that the score was improved from fair level to good level. On the other hand, the score of control group 
was also improved from 331 to 376 and the mean score was improved from 14.3 to 16.3 , and both of the results were classified into fair level.

In the table above can be known that in assessing language use of writing, the experimental group had higher score than the control group in post-test. The mean score of post-test in experimental group was 19.0 while in control group was 16.3. It means that outdoor learning is an effective strategy to improve language use of writing.

\section{e. Mechanic}

Table 3.10 The Pre-test and Post-test Score of Mechanic in Writing for Both Groups

\begin{tabular}{|lcccc|}
\hline \multicolumn{1}{c}{ Class } & \multicolumn{2}{c}{ Language Use } & \multicolumn{2}{c}{ Mean Score } \\
& Pre-test & Post-test & Pre-test & Post-test \\
Experimental Group & 69 & 90 & 3 & 3.9 \\
Control Group & 68 & 85 & 2.9 & 3.6 \\
\hline
\end{tabular}

In table 3.10 shows that score of experimental group was improved from 69 to 90. The mean score was also improved from 3 to 3.9. It means that the score was improved from fair level to good level. While in control group, the score was also improved too from 68 to 85 , the mean score from 2.9 to 3.6. It means that the score was improved from fair level to average level.

Based on the table above, in assessing mechanic of writing shows that experimental class still dominated and had higher score better than control group. It is proof that the use of outdoor learning strategy has good effect to improve mechanic of writing.

\section{B. DISCUSSION}

In this research, the researcher discussed the result above findings according to the scope of this research. The discussion intended to describe the students improving in writing through outdoor learning strategy.
1. Discussion of pre-test and post test

a. Experimental Group

Before giving treatment, the student have low categorized in writing description, it cause by the student still didn't know about the writing description process and low ability to find idea in writing. So the mean score of pre-test in experimental class was 64.6, and in the control class was 60.8 . So the students' score were classified into average.

After they were given a treatment four times through outdoor learning strategy, the writing description of the students had improved, it proved by the mean score (78.7) based on the result of posttest. It was caused by the students had known the process of writing description and had ability to find new ideas through outdoor visual. And in the control class, actually the writing description of the students had improved too but the mean score of the students (69.9) and it was still lower than the mean score of experimental class.

From both of the date scores, we could compare between the result pretest and posttest. There were 7 (30.4\%) 
students got very good categorized in post-test and none student got very good categorized in the pre-test, and there were $4(17.4 \%)$ students got good categorized in the pre-test and there are $12(52.2 \%)$ students in the post-test. There were $3(13.0 \%)$ students got poor categorized and none student got poor in the post-test.

\section{b. Control Group}

In the pre-test, students still have low categorized in writing description. It was proved by the mean score of pre-test (60.8) after four times they were taught about writing description (conventional way) without using outdoor learning strategy, the writing ability of the students had improved, it was proved by the value of mean score (69.9) but it was still low classification.

From both of the data scores, we could compare between the result pretest and post-test. None of the students got very good classification in pre-test and post-test. There was 1 (4.3\%) student good categorized in pre-test, and there were 8 (34.7\%) students got good classification in post-test. Then there were 18 (78.3\%) students got average classification in the pre-test, and there were 14 (61.0\%) students got average classification in posttest, and there were 4 $(174 \%)$ students got poor classification in pre-test and there was 1 (4.3\%) students got poor classification in post-test.

\section{Discussion of t-test and t-table}

Based on the students' result obtained and stated in finding above, the researcher used t-test in inferential statistic through SPSS version 20.0 program to test the hypothesis. On statistic test result, it showed that the probability value is lower than alpha $(\alpha)$
$(0.000<0.05)$. The t-test value for post-test (4.037) was higher than t-table value (2.021), where $N_{1}: 23$ and $N_{2}: 23$ with degree of freedom (df) $N_{1}+N_{2}-2: 44$. It means that $\mathrm{H}_{1}$ was accepted and $\mathrm{H}_{0}$ was rejected. It is concluded that there was difference between writing ability in experimental group and control group. In other words, there was an improvement on the students writing ability after applying outdoor learning in the tenth grade students of SMA Negeri 1 Maiwa kabupaten Enrekang.

From explanation above, it had been provided that the students who were taught outdoor learning strategy was better than the students who were not taught outdoor learning. It was proved by the mean score of pre-test in experimental class was higher than the mean score of post-test in control class. It support the statement of Tallent from a number of studies that the most effective way of learning is through participation, and calls on educators to make a special effort to create opportunities for children to participate in their learning.

The researcher also found that both of pre-test and post-test, the final score of the experimental class in the part of writing test were higher than final score of control class. Furthermore, the result of the research also support the statement of $W$. Nixon that using the real world is the way learning has happened for $99.9 \%$ of human existence. Only in the last years have we put it into little box called classroom.

\section{CONCLUSION}

In relation to the research findings and discussion in the previous chapter, the conclusions are presented in the following statements; the data shows that the students writing productivity before 
and after treatments are significantly difference. It was found in post-test of experimental group where the mean score was 78.7 and standard deviation 9.2 was higher than the pre-test where the mean score was 64.6 and standard deviation was 7.9, which proved that the use of outdoor learning strategy in teaching writing contributed to the students' more productive in writing English. While in control group, the mean score and standard deviation was rise up too but not significantly from 60.8 to 69.9. Meanwhile the T-test of the students' writing ability on experimental and control group in pre-test value was lower than T-table $(1.741<2.021)$. While in posttest, the T-test value was higher than Ttable (4.037>2.021). This led to the conclusion that the using of outdoor learning strategy in writing has brought up an up-to-date way in English language writing of teaching

\section{REFERENCES}

[1] Anonym. 2007. The Early Years Foundation Stage. Effective Practice; Outdoor Learning.

[2] Arikunto, Suharsimi. 2006. Prosedur Penelitian: Suatu Pendekatan Praktek. Edisi Revisi VI. Jakarta: Rineka cipta.

[3] Asrifan, Andi. 2008. Increasing the Students Ability to Write Descriptive Composition at SMP Negeri 13 Parepare by using the 3Dimention Pictures. Unpublished Thesis. FKIP Universitas Muhammadiyah Parepare.

[4] Behrens, K. Rosen, L. J \& Wesley.A.1999. Writing and Reading across Curriculum. New York; Longman
[5] British Council. 2007. Empowering Asia; new Paradigms in English Language Education.5th ASIA TEFL international conference. Malaysia: MELTA.

[6] Brown K. 2010. Curriculum for Excellence through Outdoor Learning. Scotland: Smarter Scotland

[7] Depdikbud.1994. GBPP Pengajaran Bahasa Inggris SLTP. Jakarta: Direktorat Jenderal Pandidikan Pusat.

[8] Deporter. B, Reardon. M, and Nourie. S. S. 2000. Quantum Teaching.Bandung; Kaifa.

[9] Echols, J. M., \& Shadily Hasan. 1996. An English-Indonesian Dictionary. Jakarta; PT. Gramedia Jakarta

[10] Gay, L. R., et al. 2006. Educational Research Competencies for Analysis and Applications: Eight Editions. Columbus Ohio. Pearson Merrill Prentice Hall.

[11] [11] Harmer, Jeremy. 1991. The practice of English Language Teaching. London: Longman.

[12] Heaton. 1988. Writing English Language Tests. New York: Longman.

[13] Hughes, Arthur. 2006. Testing for language teachers. Second Edition. Cambridge; Cambridge University Press.

[14] Mclead, T. William. 1983. The new Collins International dictionary of the English language. Singapore: Collins U.K and graham Brash.

[15] Schater, J. 1998. The Master Teacher Series Descriptive Writing. September $2^{\text {nd }}, 2013$, from (http//:www.teachingdoctors.com)

[16] Scott, Wendy. A,.\& Treberg, Lisbeth H.Y.1990. Teaching English 
to children. Longman.New York:USA.

[17] Wishon,G.E \& Burks,Julia M.1980.

Let's write English. Revised Edition.

Washington:

Educational

Publishing Inc. 